\title{
Spatial-Temporal Evolution of Scientific Production about Genetically Modified Maize
}

\author{
Alberto Santillán-Fernández ${ }^{1,2} \mathbb{D}$, Yolanda Salinas-Moreno ${ }^{3, *}$, José René Valdez-Lazalde ${ }^{4}$ and \\ Santiago Pereira-Lorenzo 5
}

1 Catedrático-Conacyt, Colegio de Postgraduados Campus Campeche, Champotón 24450, Campeche, Mexico; santillan.alberto@colpos.mx

2 International Doctorate Program of Agricultural and Environmental Sciences, Escuela Politécnica Superior, Universidad de Santiago de Compostela, Galicia, 27002 Lugo, Spain

3 Department of Genetic, Instituto Nacional de Investigaciones Forestales, Agrícolas y Pecuarias, Campus Altos de Jalisco, Tepatitlán de Morelos 47600, Jalisco, Mexico

4 Department of Forestry, Colegio de Postgraduados Campus Montecillo, Texcoco 56230, Estado de México, Mexico; valdez@colpos.mx

5 Department of Plant Production and Engineering Projects, Escuela Politécnica Superior, Universidad de Santiago de Compostela, Galicia, 27002 Lugo, Spain; santiago.pereira.lorenzo@usc.es * Correspondence: salinas.yolanda@inifap.gob.mx; Tel.: +52-33-2219-7627

Citation: Santillán-Fernández, A.; Salinas-Moreno, Y.; Valdez-Lazalde, J.R.; Pereira-Lorenzo, S Spatial-Temporal Evolution of Scientific Production about Genetically Modified Maize. Agriculture 2021, 11, 246. https:// doi.org/10.3390/agriculture11030246

Academic Editor: Mark O. Winfield

Received: 15 February 2021

Accepted: 8 March 2021

Published: 12 March 2021

Publisher's Note: MDPI stays neutral with regard to jurisdictional claims in published maps and institutional affiliations.

Copyright: (c) 2021 by the authors. Licensee MDPI, Basel, Switzerland. This article is an open access article distributed under the terms and conditions of the Creative Commons Attribution (CC BY) license (https:// creativecommons.org/licenses/by/ $4.0 /)$.

\begin{abstract}
Maize is the grain cereal that is the basis of human and animal diets in Mexico and Latin America; it constitutes an essential crop for global food security. The objective of this study was to analyze the spatial-temporal evolution of scientific production on the theme of GMO maize, through a bibliometric analysis of the texts available in the main editorial houses (Elsevier, Scopus, and Springer), open access journal articles database (Conricyt, Scielo, Redalyc, Latindex, Claryvate Analytics, Periodica, and DOAJ), and freely accessible web search engine Google Scholar, to determine the factors that influence the impact of the studies. From 1991 to 2019, 917 texts were found whose spatial-temporal evolution showed a linear growth that concentrated in Latin America (58.56\%). The low impact (measured by the number of bibliographic citations) of scientific studies developed in countries of Latin America was related to their publication in journals edited in their own countries and in Spanish, which restricts the constructive criticism of peer review. For the case of Mexico, a spatial discrepancy was also found between research centers and production areas, which limits the transference of technology; and no specialized author in theme of GMO maize was found; the researchers responded to "scientific trends" in agreement with the agrarian policies of the time.
\end{abstract}

Keywords: Zea mays L.; academic endogamy; scientific article; scientific trends

\section{Introduction}

Maize (Zea mays L.) is the cereal with highest worldwide production level, above wheat (Triticum aestivum L.) and rice (Oryza sativa L.), and it constitutes the basis of the human diet for countries of Latin America, especially Mexico, where it is considered a strategic crop for the country's food security [1]. With the development of biotechnology, GMO maize varieties have been created with resistance to insects and herbicides, which allows productivity to increase by area [2].

Maize is originally from Mexico, territory where 64 races are cultivated derived from the millenary domestication process of its wild relatives, Teocintle and Tripsacum, in combination with different environments, agricultural systems and ethnic groups [3]. However, despite this diversity of maize races, Mexico is not the main maize producer in the world. Of global production, $70.06 \%$ is concentrated in five countries, with USA (35.42\%) and China (21.93\%) as the leading producers, followed by Brazil (7.22\%), Argentina (3.01\%), and Mexico $(2.48 \%)$ [1]. 
Unlike Mexico, USA, China, Brazil, and Argentina base their productivity on the use of GMO maize varieties, which provide higher yields in the field than the conventional varieties [4]. Reference [5] found that the agricultural competitiveness of a country is directly related with the quality of the research performed in this sector. To measure the quality of research, [6] suggest a methodology of bibliometric analysis that allows studying and analyzing the evolution of scientific activity through its publications.

The publication of a scientific study is the most effective way to transmit knowledge acquired as consequence of the research, and its visibility is important for the researchers themselves, for the institutions where they work, and for the organizations that finance the research [7]. The growth of scientific production in recent decades and their indexation in automatized bibliographic databases have strengthened the use of bibliometry and the generation of indicators to measure the results of scientific and technological activity [8].

Bibliometric studies based on the scientific articles published are supported by the application of quantitative methods, generation of indicators and mathematical models, which allow characterizing their development and evolution [9]. Through bibliometric indicators, the journals and other periodic publications can be evaluated objectively, and the trends that they follow can be observed to generate useful information to improve their management [7].

Understanding the scientific information that is developed around a topic allows making decisions in relation to its improvement [10]. Bibliometric studies have been developed in the agricultural sector to evaluate general themes of agronomy [6], specific themes such as ecological agriculture [11], fruits and vegetables [12], and even for agronomists in particular [13], agricultural journals [14], national agricultural sectors [8], and specific crops such as wheat and barley [15], and rice $[9,16]$.

However, despite the growth in the number of publications that has taken place in the agricultural sector and specifically in themes related to transgenic maize, there is scarce research to assess the evolution and the impact of these publications at the level of the user [17]. Considering this, the objective of the present study was to analyze the spatial-temporal evolution of scientific production on the theme of GMO maize at the global level, and with emphasis for Mexico, through text mining (bibliometry) and Social Network Analysis (SNA) to determine the factors that impact the quality of the studies.

\section{Materials and Methods}

\subsection{Origin of the Information and Data Preparation}

Scientific articles about transgenic maize available in the principal editorial houses (Elsevier, Scopus, and Springer), open access journal articles database (Conricyt, Scielo, Redalyc, Latindex, Claryvate Analytics, Periodica, and DOAJ), and freely accessible web search engine Google Scholar were considered in this study. They were compiled from January to April 2020. It was considered all scientific articles available up 2019. The keywords used in the search were "maíz transgénico", "maíz genéticamente modificado", "genetically modified corn" and "transgenic corn", identifying them in the titles and keywords of the publications. In addition, the "snowball" technique was used to obtain the missing articles, from the reference list of the articles initially found. However, it has to be considered that the technique of "snowball" as being non-probabilistic, has the possibility of incurring in bias, while recovering the scientific articles, favoring the documents in English. For upcoming this bias, in the search of the scientific articles, the keywords used were both in English and Spanish, what let to obtain the great majority of important publications [18].

In order to establish the bibliometric indicators, the variables analyzed from each of the articles were "name of the journal, editing institution, country of edition", and "language of publication", which served to determine the profile of the journals that publish studies related to the theme of "GMO maize; first author and collaborators" which served to understand the network of actors involved in the research; "year" used in order to place the 
information in a time line; "institution of the first author" and "the first author's country of origin" to evaluate the frequency of publications of institutions by country.

The "postal code of the institution of the first author" served to perform a geographic localization of the information's institution of origin; in the cases when the postal address did not appear, the name of the institution was searched with Google Earth ${ }^{\circledR}$ tools and in the official pages of the institutions. The "title, abstract" and "keywords" were used to categorize the topic addressed by the publication in agreement with the classification by the National Resource Consortium of Scientific and Technological Information [19] for genetically modified maize. Finally, the usefulness of the publications was determined with the "number of citations".

Capturing the variables was done in a worksheet, in which they were systematized and classified in thematic areas according to their content; in addition, the original language of each of the texts was respected. While capturing all the information, some records were standardized because the information available in the articles was sometimes incomplete or presented with variations [20]. In addition, special characters were eliminated or changed to ease the analysis, such as: $\tilde{n}$ (by n), accent marks, superindex, subindex ${ }^{\circledR},{ }^{\circledR}$, , among others. Due to interpretation reasons, the information for the case of Mexico was separated into three periods that coincide with the periods of three government administrations: 2001-2006, 2007-2012, and 2013-2018.

\subsection{Analysis with Text Mining}

With the help of the RcmdrPlugin.temis complement of the statistical software R [21], the number of articles per year and journal, the institution where the research originated, and the articles where the main author is from the same institution of the journal were obtained.

\subsection{Network Analysis}

With the Sci2tool software [22] the interactions present between the first authors and collaborators were analyzed with the aim of understanding the consistency of the researcher's work; that is, to assess whether the author has published just in one year or else has been publishing constantly throughout time, which gives an idea of the author's consolidation on the topic of GMO maize. The syntaxis used with the Sci2tool software was Extract bipartite Network, and for its visualization the Gephi software was used [23].

Finally, with the help of the variable "postal code" and Google Earth ${ }^{\circledR}$ tools, the geographic coordinates in tenths of degree were obtained (Longitude, Latitude) of each of the articles published. The spatial representation of the number of articles per institution was carried out with the geographic package ARGIS ${ }^{\circledR}$ [24].

\section{Results and Discussion}

\subsection{Scientific Production on GMO Maize in the International Context}

From 1991 to 2019, a total of 917 scientific articles were published, which resulted in 20,997 bibliographic citations (Figure 1). The first study recorded dates from 1991; however, since 2000 a growing production was seen for the topic of "GMO maize". The period of highest productivity was from 2008 to 2018 with $76.23 \%$ of the total (699 articles). The most frequently cited studies were those published in 2003, 2004, and 2005 which together resulted in 6245 citations (29.74\%).

Based on the first author's country of origin in the scientific articles, 917 studies originated in 53 countries. Of these, $74.81 \%$ (686) were concentrated in seven countries: Mexico (24.24\%, 225 articles), USA (17.99\%, 165), Brazil (8.40\%, 77), Colombia (8.40\%, 77), Argentina $(5.56 \%, 51)$, Spain $(5.34 \%, 49)$, and China $(4.58 \%, 42)$. The fact that the countries with highest scientific production are the countries with greatest maize grain production globally stands out (Figure 2). Figure 2 also shows that the countries with highest number of publications are located in Latin America, which explains that $55.29 \%$ (507 articles) are 
published in Spanish, 39.59\% (363) in English, 3.93\% (36) in Portuguese, and 1.20\% (11) in other languages (primarily French, Mandarin, and Russian).

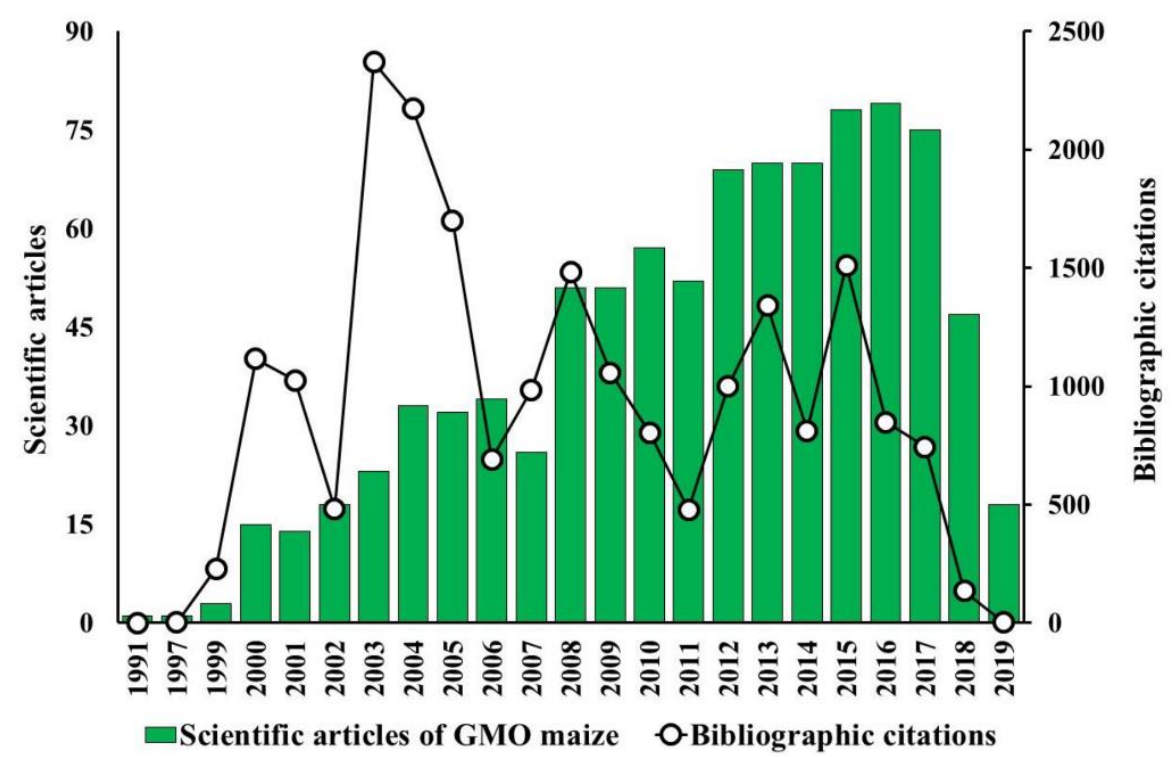

Figure 1. Temporal evolution of scientific production and bibliographic citations on the topic of GMO maize worldwide from 1991 to 2019.

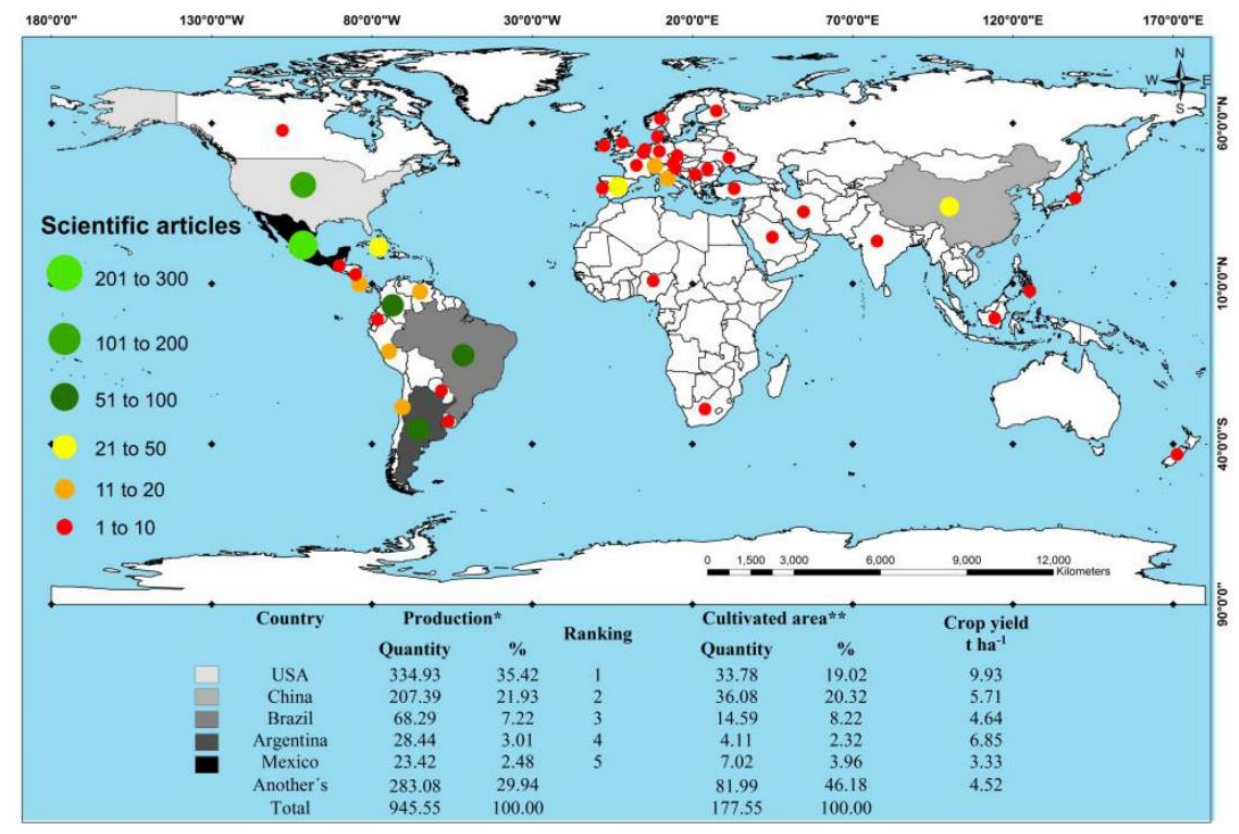

Figure 2. Spatial relation of the production of scientific articles on the topic of GMO maize with productivity indicators in the field from 1991 to $2019\left({ }^{*}\right.$ millions $t,{ }^{* *}$ millions ha) adapted from [1] with permission from FAOSTAT (2020).

According to the classification by [19], with 34 theme areas regrouped into six categories, the following results were obtained: (1) Productivity (agriculture, botany, and ecology), $36.21 \%$ of the total articles; (2) Competitiveness (economy and social sciences), 17.34\%; (3) Pests and diseases (zoology and biology), 15.81\%; (4) Public health (medicine and nutrition), 8.72\%; (5) Cultural (anthropology, history, and archaeology), 4.25\%; and (6) Others (engineering, geography, chemistry, law, and various topics), $17.67 \%$.

In the case of the main countries that recorded scientific production about GMO maize, the themes of productivity $(26.28 \%, 241$ articles $)$, pests and diseases $(12.65 \%, 116)$, and com- 
petitiveness $(12.10 \%, 111)$ had the highest frequencies in scientific articles (Figure 3). [25] found that the policy that the USA adopted to encourage the development of technological innovations, allowed it to become the principal maize producer in the world. In contrast with Mexico, where the development of research consisted mostly in demonstrating the irrelevance of transgenic maize $[17,25]$.

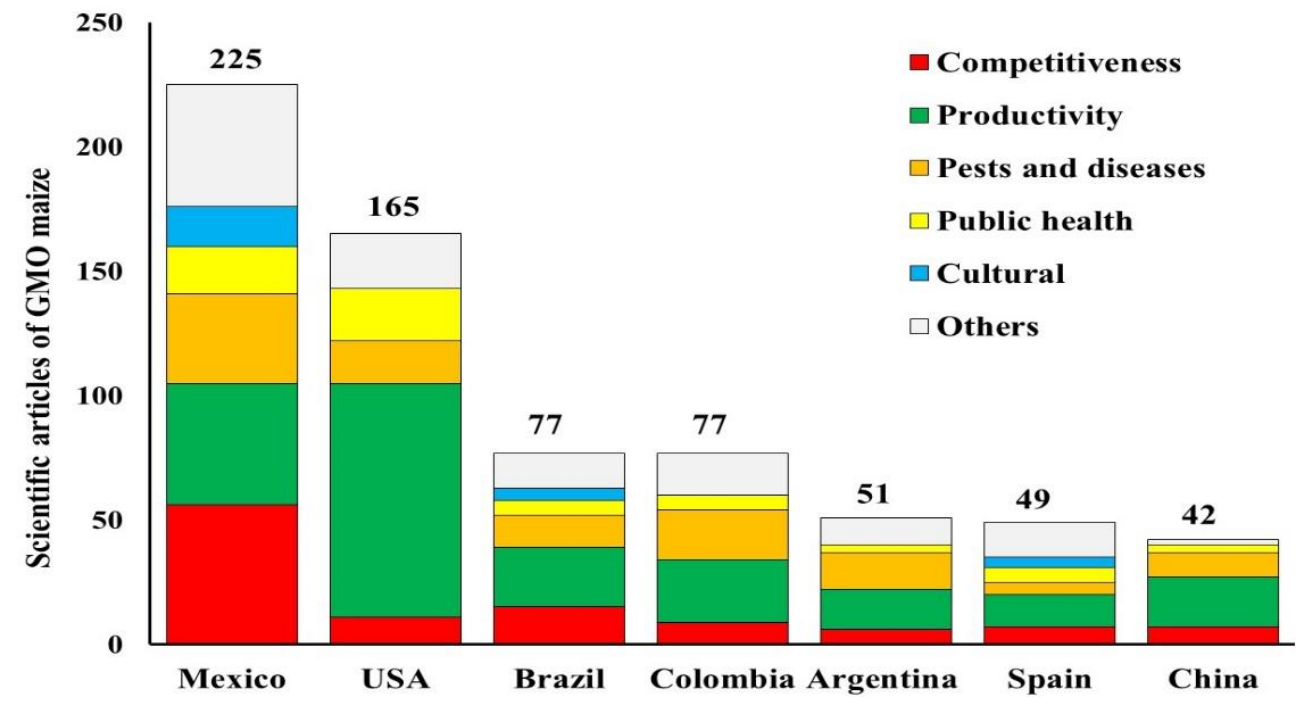

Figure 3. Principal nations and research they address, according to the first author's country of origin in scientific articles on GMO maize from 1991 to 2019.

In the 917 articles analyzed, 703 first authors were found, between author and collaborators they were 2360 different individuals in total. The mean of co-authorship was 2.57 and the mode (160) of 3 authors per article, with extreme values of a single author (29 articles) and 6 studies with more than 12 authors. The network of authors and collaborators (Figure 4) was made up of 2360 nodes (authors) and 2132 aspects (links). The links in a SNA are important because it is through them that an author can reach certain ideas, knowledge and information that is socially distant for him [26].

\section{Chaparro_Giraldo_A}

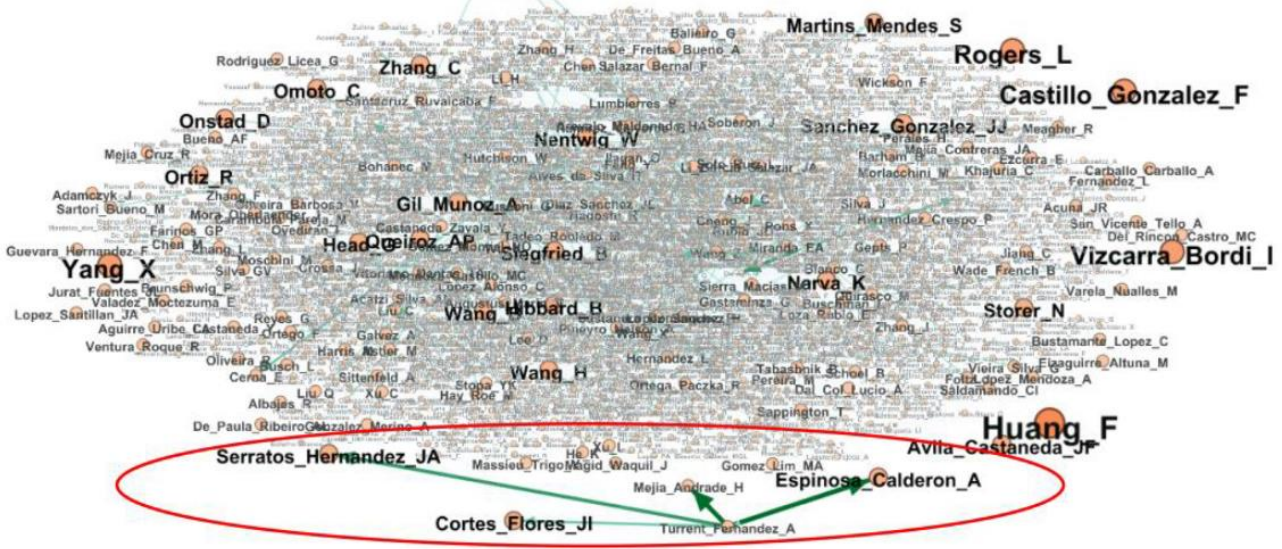

Figure 4. Network of authors and coauthors worldwide that have published scientific articles on GMO maize from 1991 to 2019. The size of the node corresponds to their productivity. The arrow connections refer to the association among authors. The arrows thickness is related with the frequency of which the authors interact. The ellipse identifies a sub-network formed by Mexican researchers. 
The density of the network had a value of 0.001, implying that for the topic of GMO maize there is not much collaboration between authors in the international context. This is evident since there are 501 institutions (from 917 studies) indicated as the ascription of the first author. The density is an indicator of the SNA that implies that both the nodes interact (are linked) between one another, mathematically it is a value within the interval (0 to 1$)$, the closer to 1 the higher the interaction in the network [27].

The institutions with highest frequency ( $\geq 19$ scientific articles) were: (1) UAM, Mexico, 36 articles, principal author Massieu_Trigo_Y; (2) UNAM, Mexico, 34, Cortes_Flores_JI; (3) UNC, Colombia, 33, Chaparro_Giraldo_A; and (4) COLPOS, Mexico, 19, Castillo_González_F. It should be noted that Chaparro_Giraldo_A from the UNC was the author with most contributions, with a total of 20 (seven as first author and 13 as coauthor).

A subnetwork formed by Mexican researchers was detected (Figure 4): Espinosa Calderon_A, Mejia_Andrade_H and Turren_Fernandez_A from INIFAP; Cortes_Flores_JI (UNAM); Serratos_Hernandez_JA (UACM) and Massieu_Trigo_Y (UAM). As a whole, the researchers in the subnetwork are part of the Union of Scientists Committed with Society in the Agriculture and Food Program (Transgenic Maize Group) [28].

\subsection{Bibliometric Indicators}

The 917 studies analyzed were published in 449 scientific journals. A total of 248 articles, $27.05 \%$ and 8628 bibliographic citations, $41.09 \%$, were found in 20 journals (Table 1). Among these 20 main journals, 13 are from Latin American countries: Mexico (5), Colombia (4), Argentina (1), Cuba (1), Venezuela (1), and Brazil (1); they publish mostly in Spanish and do not have a JCR impact factor or a very low factor (Q4), which according to [29] limits the number of bibliographic citations since English is the language adopted as universal by the scientific community.

The low impact (bibliographic citations) of the scientific studies developed in countries of Latin America is related to the fact that the researchers publish their studies in national journals (Table 2), edited in Spanish; meanwhile, the journals of highest impact are found in English-speaking countries (United Kingdom and USA) [31], published in English. This explains the high impact of articles from USA, with $63.03 \%$ of their studies published in journals of their own country, and the remaining percentage in journals of other countries also edited in English.

Among the 20 most cited studies about GMO maize themes, 14 belong to a first author whose institution of ascription is localized in USA and only one study corresponds to a researcher in Latin America (Mexico); they have all been published in English and in journals of English-speaking origin (Table 3). According to [5] the economic development of a country is directly related to the quality of the research it performs; countries with consolidated economies (USA, Switzerland, Italy, and China) invest more in their research centers, which allows them higher technological development, compared to underdeveloped economies like the Latin American where investment in research is lower. In addition, some of these consolidated economies (Switzerland, Italy, and China), whose native language is not English, also publish their studies of higher impact in this language, the same in which most of the indexed journals included in the Journal Citation Report are edited, which is included in the Web of Science (WoS) and belongs to an information company in USA, Thomson Reuters [30]. 


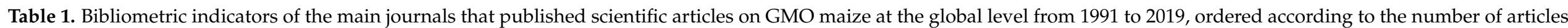
published.

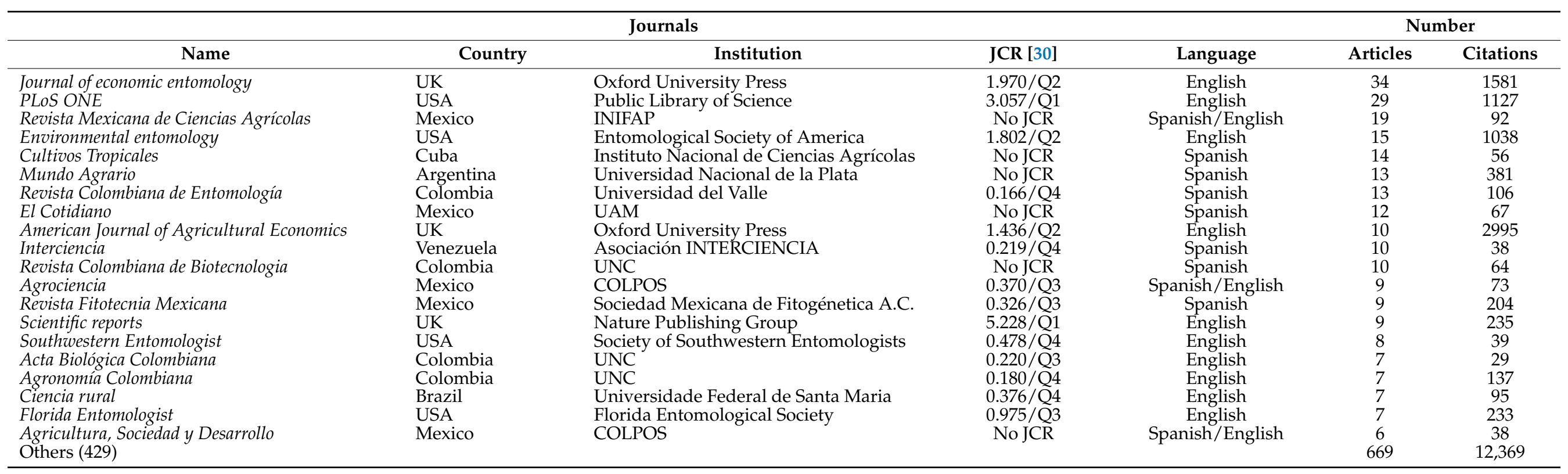




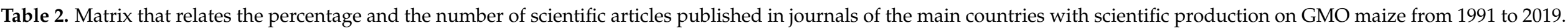

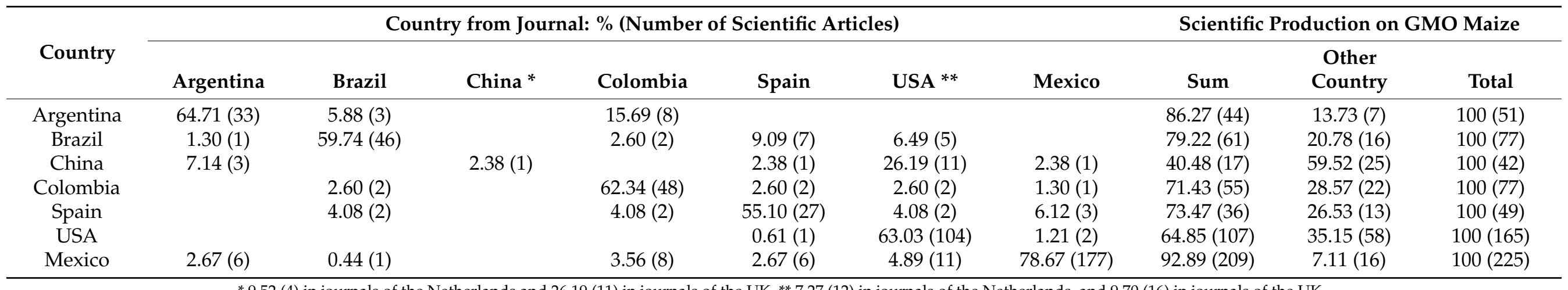

Table 3. Bibliometric indicators of the main scientific articles on GMO maize worldwide from 1991 to 2019, ordered according to the number of bibliographic citations.

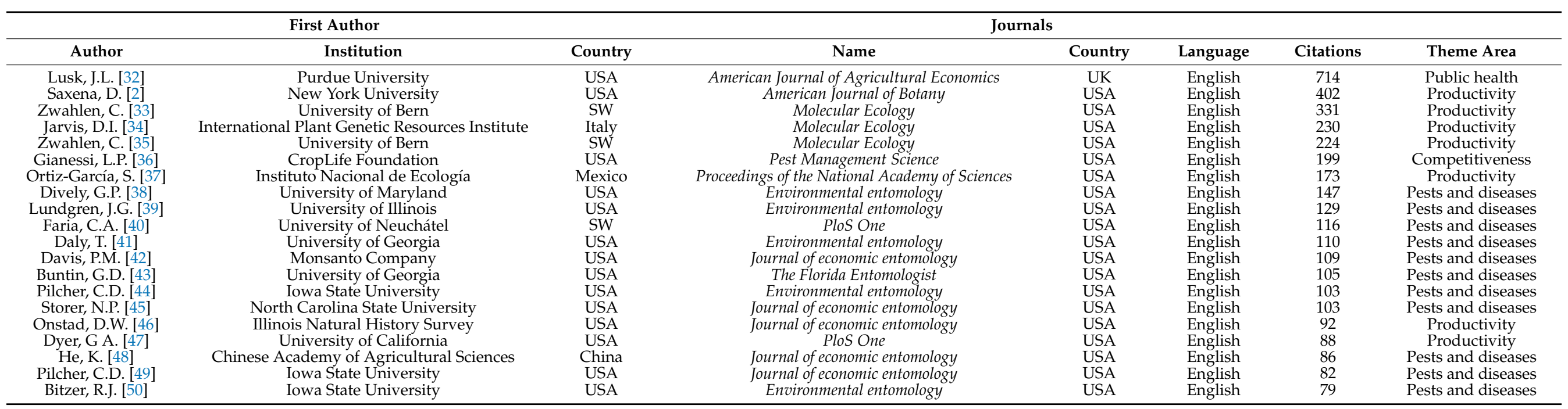




\subsection{Scientific Production on the Theme of GMO Maize in Mexico}

From 1991 to 2019 Mexican researchers published 225 scientific articles on the topic of GMO maize. From the 225 studies, 163 (72.44\%) were developed in 11 of 50 institutions, taking as reference the institution of ascription of the first author. The institutions with highest productivity were UAM (36 studies), UNAM (34), COLPOS (19), CHAPINGO (15), INIFAP (14), and IPN (12). Due to tradition, in CHAPINGO (founded in 1854), COLPOS (1959) and INIFAP (1985), the studies published stemmed from the initiatives to develop agricultural research.

The spatial distribution of the institutions with scientific productivity on GMO maize (1991-2019) (Figure 5) allows deducing that research on this topic is located in the center of the country, while in terms of the states with highest maize grain production in Mexico from 2000 to 2019, the areas with highest production are in the north (Sinaloa and Chihuahua), east (Jalisco, Michoacán, Guanajuato, and Estado de México), northeast (Tamaulipas and Veracruz), and southeast (Chiapas) of Mexico. This aspect of the centralization of research has been addressed by [10], who found that the discrepancy between the production areas and the research centers makes the transference of technology difficult.

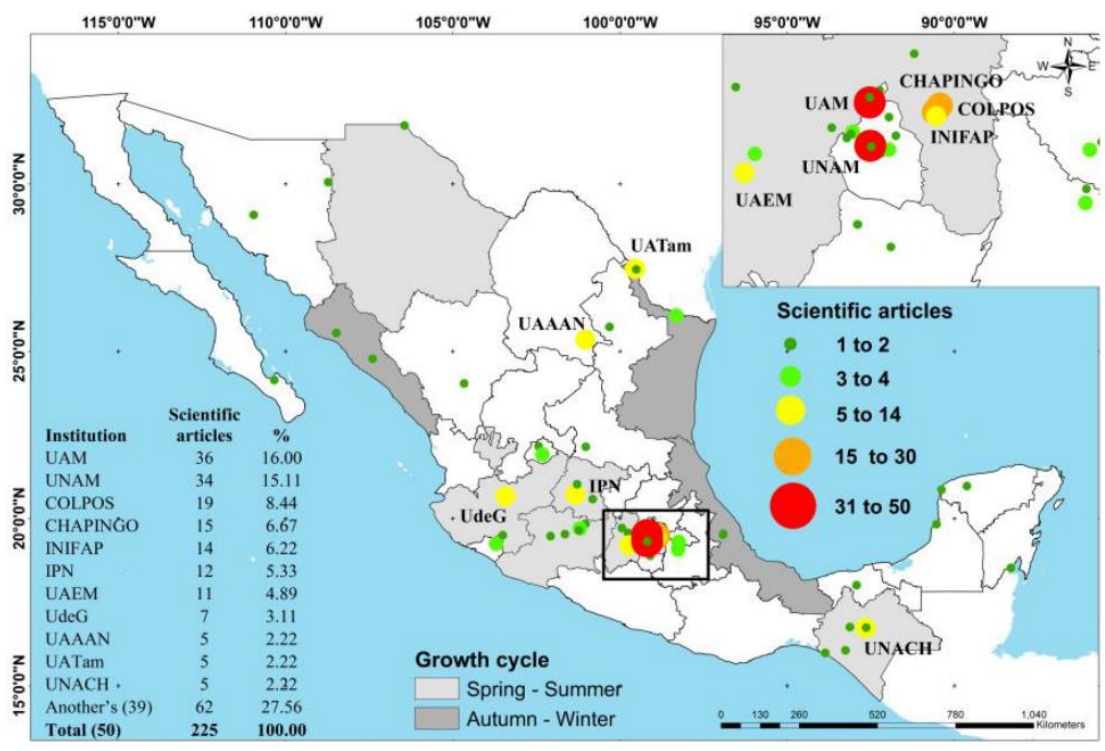

Figure 5. Spatial distribution of academic and research institutions in Mexico that published articles on GMO maize from 1991 to 2019, and main production areas.

The language preferred by Mexican researchers to publish their results on GMO maize was Spanish with $88.44 \%$ (199) of the studies, followed by English for the remainder $11.56 \%$ (26). The themes of most interest were those related with competitiveness (56 studies, $24.89 \%)$ and productivity $(49,21.78 \%)$ directed at showing the irrelevance of GMO maize in the Mexican farmland. The 225 studies were published in 123 different journals, 86 of which were edited by national institutions that in total published 177 articles $(78.67 \%)$.

In Mexico, most of the researchers published their studies about GMO maize in journals edited by their institution of ascription (Table 4), which restricts the constructive criticism of peer review and, according to [51,52], is indicator of the low impact of the publications, since it limits the feedback from interdisciplinary groups regarding the relevance of the research. In this regard, [10,53] found that research in Mexico not only presents "academic endogamy" but also that the researchers in their eagerness to remain in the Sistema Nacional de Investigadores-Consejo Nacional de Ciencia y Tecnologia (SNI-CONACYT) tend to replicate the same methodologies in different study areas, which limits innovation in research and allows the circularity (redundancy in the study object) of the publications. 


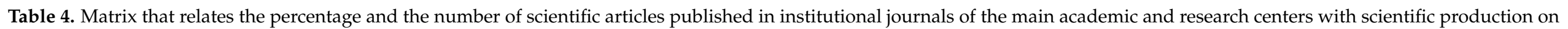
GMO maize from 1991 to 2019 in Mexico.

\begin{tabular}{|c|c|c|c|c|c|c|c|c|c|c|c|}
\hline \multicolumn{3}{|c|}{ Journal } & \multicolumn{8}{|c|}{ First Author Institution } & \multirow{2}{*}{ Total } \\
\hline Name & Institution & JCR [30] & Language & UAM & UNAM & COLPOS & CHAPINGO & INIFAP & IPN & Others & \\
\hline $\begin{array}{l}\text { Revista Mexicana de Ciencias } \\
\text { Agrícolas } \\
\text { El Cotidiano } \\
\text { Agrociencia } \\
\text { Revista Fitotecnia Mexicana } \\
\text { Argumentos } \\
\text { Agricultura, Sociedad y Desarrollo } \\
\text { Soociologica } \\
\text { Acta Universitaria } \\
\text { Sociedad y Ambiente } \\
\text { AGROProductividad } \\
\text { Revista de Geografia Agricola }\end{array}$ & $\begin{array}{l}\text { INIFAP } \\
\text { UAM } \\
\text { COLPOS } \\
\text { Fitogenetica A.C.* } \\
\text { UAM } \\
\text { COLPOS } \\
\text { UAM } \\
\text { UGTO } \\
\text { ECOSUR } \\
\text { COLPOS } \\
\text { CHAPINGO }\end{array}$ & $\begin{array}{l}\text { No JCR } \\
\text { No JCR } \\
0.370 / Q 3 \\
0.326 / Q 3 \\
\text { No JCR } \\
\text { No JCR } \\
\text { No JCR } \\
\text { No JCR } \\
\text { No JCR } \\
\text { No JCR } \\
\text { No JCR }\end{array}$ & $\begin{array}{l}\text { Spanish/English } \\
\text { Spanish } \\
\text { Spanish/English } \\
\text { Spanish } \\
\text { Spanish } \\
\text { Spanish/English } \\
\text { Spanish } \\
\text { Spanish } \\
\text { Spanish } \\
\text { Spanish } \\
\text { Spanish/English }\end{array}$ & $\begin{array}{c}10.53(2) \\
50.00(6) \\
100.00(8) \\
80.00(4)\end{array}$ & $\begin{array}{c}8.33(1) \\
11.11(1)\end{array}$ & $\begin{array}{l}15.79(3) \\
44.44(4) \\
55.56(5) \\
50.00(3)\end{array}$ & $\begin{array}{l}10.53(2) \\
22.22(2) \\
33.33(2) \\
20.00(1)\end{array}$ & $\begin{array}{l}36.84(7) \\
11.11(1)\end{array}$ & $\begin{array}{l}60.00(3) \\
40.00(2)\end{array}$ & $\begin{array}{l}26.32(5) \\
33.33(4) \\
33.33(3) \\
22.22(2) \\
16.17(1)\end{array}$ & $\begin{array}{l}100.00(19) \\
100.00(12) \\
100.00(9) \\
100.00(9) \\
100.00(8) \\
100.00(6) \\
100.00(5) \\
100.00(5) \\
100.00(5) \\
100.00(5) \\
100.00(4)\end{array}$ \\
\hline
\end{tabular}


Finally, the network of authors and collaborators for the case of the publications where the first author was ascribed to a Mexican institution was divided into three periods: 2001-2006, 2007-2012, and 2013-2018. The periods proposed correspond to the policies that prevailed in the country during the different governments.

By periods, the number of authors went from 59 in 2001-2006 to 130 in 2007-2012, and 291 in 2013-2018. The articles also increased from 24 to 76 and 111, respectively (Supplementary Table S1). According to [10] the increase in authors and articles that Mexico has been having in the agriforest sector is because the SNI-CONACyT awards more the quantity than the quality. In turn, [54] found that the agricultural policies adopted by Mexico during its different governments have encouraged the development of research on the theme of GMO maize.

With the promulgation of the Sustainable Rural Development Law in 2001 [55], research began in Mexico on the topic of GMO maize, while before that the studies were centered on attaining the best yields with native germplasm or improved through hybridization [54]. The government in 2007-2012 encouraged the use of GMO seed and the studies were focused on highlighting the geopolitical irrelevance of this biotechnology in Mexico as center of origin and domestication of maize [17]. Finally, the government in 2013-2018 motivated the use of improved maize varieties (native) through the Traditional Agriculture Sustainable Modernization Program (MasAgro) and the studies revolved around arguing that it is possible to achieve self-sufficiency (food security) without the need of resorting to the use of GMO varieties [54]. Of the scientific articles analyzed, $90 \%$ agree that it is not convenient the growth of GMO maize in Mexico. The main argument to this position is that Mexico is the main center of origin and domestication of maize, so there is a great genetic diversity of this species and there are close cultural connections between maize and the different native peoples.

The co-authorship networks built according to the degree of entry of the authors in the network allowed identifying the importance (reference) of the author in the network, by quantifying the number of links that an author receives from others [27]. In 20012006, there was not an author with high reference, and three authors were found with medium reference (Soberon_J, Schoel_B and Ezcurra_E) (Figure S1). In 2007-2012, there was an author with high reference (Castillo_González_F) (Figure S2), and in 2013-2018, two (Vizacarra_Bordi_I and Avila_Castaneda_JF) (Figure 6), the authors of medium reference increased in 5 and 18, respectively (Table S1). However, despite these increases, from 2001 to 2018 there was not an author observed whose research was constant, which points to there not being in the country any specialists in the theme, but rather research responded to scientific trends in agreement with the agrarian policies of the moment.

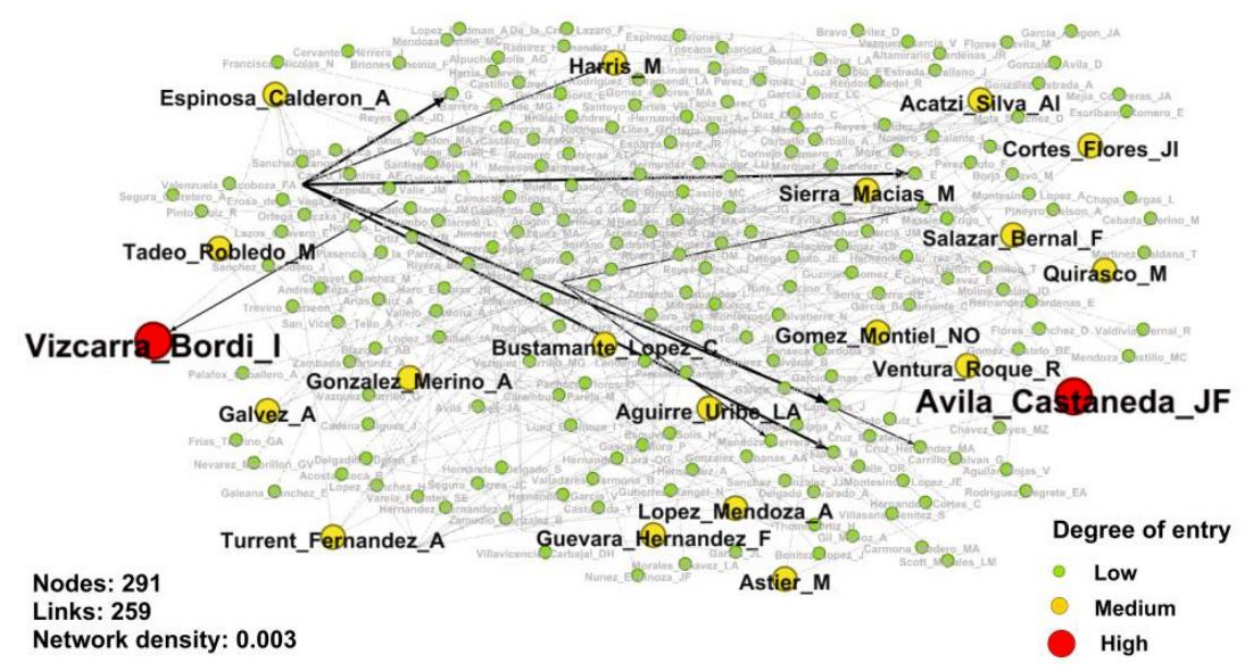

Figure 6. Network of authors and coauthors for the 2013-2018 period who published scientific articles on GMO maize where the first author is Mexican. 


\section{Conclusions}

The spatial-temporal evolution of scientific production showed a linear growth of scientific studies worldwide about GMO maize, which were concentrated primarily in countries of America, with special emphasis in Latin America: Mexico, Colombia, Argentina, Brazil, and Cuba. The themes of greatest relevance were those related to productivity $(26.28 \%)$, pests and diseases $(12.65 \%)$, and competitiveness $(12.10 \%)$. However, the relevance (measured by number of citations) of scientific production in Latin America was nearly null, as a result of the publication in journals edited in the countries themselves, in Spanish, when the journals of impact are led by English-speaking countries, in English. For the case of Mexico, a centralization of research was found with spatial discrepancy from the production areas; a phenomenon called academic endogamy which consists in publishing in journals edited by the authors' own institution; and an author with constant production was not observed during the period of analysis, but rather the researchers responded to "scientific trends" in agreement to the agrarian policies of the moment. Therefore, research on GMO maize in Latin America has a broad margin of improvement through the publication of texts in English and higher impact journals, which can contribute to agricultural competitiveness of the sector in each country.

Supplementary Materials: The following are available online at https:/ /www.mdpi.com/2077-0 472/11/3/246/s1, Figure S1: Network of authors and coauthors for the 2001-2006 period who published scientific articles on GMO maize where the first author is Mexican, Figure S2: Network of authors and coauthors for the 2007-2012 period who published scientific articles on GMO maize where the first author is Mexican, Table S1: Indicators of the co-authorship networks for the periods 2001-2006, 2007-2012, and 2013-2018 of scientific articles published on GMO maize where the first author is Mexican.

Author Contributions: Conceptualization, information analysis and writing of original draft, A.S.-F.; Data review and monitoring results, Y.S.-M.; Information analysis and writing of final manuscript, J.R.V.-L.; Writing, revising, and editing of the final manuscript, S.P.-L. All authors have read and agreed to the published version of the manuscript.

Funding: This research received no external funding.

Institutional Review Board Statement: Not applicable.

Data Availability Statement: Availability of data. The data are available with the author for correspondence, at reasonable request.

Acknowledgments: This study is part of the doctoral thesis of the first author in the International Doctorate Program of Agricultural and Environmental Sciences of the Universidad de Santiago de Compostela, Spain; and to Project number 364. Sustainable productive reconversion for the development of rural producers in Campeche, assigned to the first author by the Consejo Nacional de Ciencia y Tecnologia (CONACyT). To the anonymous reviewers of the article, for their comments, which helped to enrich the research.

Conflicts of Interest: The authors declare no conflict of interest.

\footnotetext{
Abbreviations

CHAPINGO, Universidad Autónoma Chapingo; COLPOS, Colegio de Postgraduados; ECOSUR, El Colegio de la Frontera Sur; GMO maize, Genetically Modified Maize; INIFAP, Instituto Nacional de Investigación Forestal, Agrícola y Pecuaria; IPN, Instituto Politécnico Nacional; JCR, Journal Citation Reports; SNA, Social Network Analysis; SNI-CONACYT, Sistema Nacional de Investigadores-Consejo Nacional de Ciencia y Tecnologia; SW, Switzerland; UAAAN, Universidad Autónoma Agraria Antonio Narro; UACM, Universidad Autónoma de la Ciudad de México; UAEM, Universidad Autónoma del Estado de México; UAM, Universidad Autónoma Metropolitana; UATam, Universidad Autónoma de Tamaulipas; UdeG, Universidad de Guadalajara; UGTO, Universidad de Guanajuato; UK, United Kingdom; UNACH, Universidad Autónoma de Chiapas; UNC, Universidad Nacional de Colombia;
} 
UNAM, Universidad Nacional Autónoma de México; USA, United States of America.

\section{References}

1. FAOSTAT. The Food and Agriculture Organization Corporate Statistical Database. Crops. Available online: http://www.fao.org/ faostat/es/\#data/QC (accessed on 17 February 2020).

2. Saxena, D.; Stotzky, G. Bt corn has a higher lignin content than non-Bt corn. Am. J. Bot. 2001, 88, 1704-1706. [CrossRef] [PubMed]

3. Dyer, G.A.; Taylor, J.E. A crop population perspective on maize seed systems in Mexico. Proc. Natl. Acad. Sci. USA 2008, 105, 470-475. [CrossRef]

4. Mottaleb, K.A.; Loladze, A.; Sonder, K.; Kruseman, G.; Vicente, F.S. Threats of Tar Spot Complex disease of maize in the United States of America and its global consequences. Mitig. Adapt. Strat. Glob. Chang. 2019, 24, 281-300. [CrossRef]

5. Gersbach, H.; Schneider, M.T. On the global supply of basic research. J. Monet. Econ. 2015, 75, 123-137. [CrossRef]

6. Cañas-Guerrero, I.; Mazarrón, F.R.; Pou-Merina, A.; Calleja-Perucho, C.; Díaz-Rubio, G. Bibliometric analysis of research activity in the "Agronomy" category from the Web of Science, 1997-2011. Eur. J. Agron. 2013, 50, 19-28. [CrossRef]

7. Chao, C.-C.; Yang, J.-M.; Jen, W.-Y. Determining technology trends and forecasts of RFID by a historical review and bibliometric analysis from 1991 to 2005. Technovation 2007, 27, 268-279. [CrossRef]

8. Bravo-Vinaja, Á.; Sanz-Casado, E. Análisis bibliométrico de la producción científica de México en Ciencias Agríco-las durante el periodo 1983-2002. Rev. Fitotec. Mex. 2008, 31, 187-194.

9. Peng, S.-B. Booming research on rice physiology and management in China: A bibliometric analysis based on three major agronomic journals. J. Integr. Agric. 2017, 16, 2726-2735. [CrossRef]

10. Martínez-Santiago, S.Y.; Alvarado-Segura, A.A.; Zamudio-Sánchez, F.J.; Cristóbal-Acevedo, D. Spatio-temporal analysis of forest modeling in Mexico. Rev. Chapingo Ser. Cienc. Y Del Ambient. 2017, 23, 5-22. [CrossRef]

11. Aleixandre, J.L.; Aleixandre-Tudó, J.L.; Bolaños-Pizarro, M.; Aleixandre-Benavent, R. Mapping the scientific research in organic farming: A bibliometric review. Science 2015, 105, 295-309. [CrossRef]

12. Tatry, M.-V.; Fournier, D.; Jeannequin, B.; Dosba, F. EU27 and USA leadership in fruit and vegetable research: A bibliometric study from 2000 to 2009. Science 2014, 98, 2207-2222. [CrossRef]

13. Nayak, S.; Bankapur, V. Scientometric Analysis of Scholarly Publications of Agronomist Dr. GS Khush. Veethika-Int. Interdiscip. Res. J. 2017, 3, 1-14.

14. Bravo-Vinaja, Á. Impacto de la Revista Fitotecnia Mexicana y de Las Revistas Mexicanas Indexadas. Rev. Fitotec. Mex. 2015, 38, 229. [CrossRef]

15. Giraldo, P.; Benavente, E.; Manzano-Agugliaro, F.; Gimenez, E. Worldwide Research Trends on Wheat and Barley: A Bibliometric Comparative Analysis. Agron. 2019, 9, 352. [CrossRef]

16. Sun, J.; Yuan, B.Z. A bibliometric analysis of research on rice and irrigation from the 'Agronomy'category based on the Web of Science. Curr. Sci. 2020, 119, 438-446.

17. Espinosa-Calderón, A.; Turrent-Fernández, A.; Tadeo-Robledo, M.; Vicente-Tello, S.; Gómez-Montiel, N.; Valdivia-Bernal, R.; Sierra-Macias, M.; Zamudio-González, B. Ley de Semillas y Ley Federal de Variedades Vegetales y transgénicos de maíz en México. Rev. Mex. Cienc. Agrícolas 2014, 5, 293-308. [CrossRef]

18. Leipold, S. Creating forests with words-A review of forest-related discourse studies. Policy Econ. 2014, 40, 12-20. [CrossRef]

19. CONACYT. Consejo Nacional de Ciencia y Tecnologia. Consorcio Nacional de Recursos de Información Científica y Tecnológica. Available online: http:/ / conricyt15.summon.serialssolutions.com.conricyt.remotexs.co/\#!/search?ho=t\&fvf=IsFullText, true, $\mathrm{f} \& \mathrm{l}=\mathrm{es}-\mathrm{ES} \& \mathrm{q}=\mathrm{maiz} \% 20$ transgenico (accessed on 25 February 2020).

20. Aguado-López, E.; Rogel-Salazar, R.; Garduño-Oropeza, G.; Becerril-García, A.; Zúñiga-Roca, M.; Velázquez-Álvarez, A. Patrones de colaboración científica a partir de redes de coautoría. Converg. Rev. Cienc. Soc. 2009, 16, 225-258.

21. Bouchet-Valat, M.; Bastin, G. RcmdrPlugin. temis, a Graphical Integrated Text Mining Solution in R. R J. 2013, 5, 188-196. [CrossRef]

22. Börner, K. Science of Science Studies: Sci2 Tool. Commun. Acm 2011, 54, 60-69. [CrossRef]

23. Bastian, M.; Heymann, S.; Jacomy, M. Gephi: An open source software for exploring and manipulating net-works. Icwsm 2009, 8, 361-362.

24. ESRI. Environmental Systems Research Institute. ArcGIS (Versión 10.3) Software de procesamiento digital de imáge-nes satelitales. Redlands, CA, USA. Available online: http:/ / www.esri.com/software/arcgis/arcgis-for-desktop (accessed on 17 March 2020).

25. González-Merino, A.; Ávila-Castañeda, J.F. El maíz en Estados Unidos y en México: Hegemonía en la producción de un cultivo. Argumentos 2014, 27, 215-237.

26. Granovetter, M.S. The Strength of Weak Ties. Am. J. Sociol. 1973, 78, 1360-1380. [CrossRef]

27. Aguilar-Gallegos, N.; Martínez-González, E.G.; Aguilar-Ávila, J.; Santoyo-Cortés, H.; Muñoz-Rodríguez, M.; García-Sánchez, E.I. Análisis de redes sociales para catalizar la innovación agrícola: De los vínculos directos a la integración y radialidad. Estud. Gerenc. 2016, 32, 197-207. [CrossRef]

28. UCCS. Unión de Científicos Comprometidos con la Sociedad. Maíz transgénico en México. Available online: https://www.uccs. $\mathrm{mx}$ /agricultura_alimentacion/maiztransgenico/ (accessed on 8 April 2020). 
29. Li, W.; Zhao, Y. Bibliometric analysis of global environmental assessment research in a 20-year period. Environ. Impact Assess. Rev. 2015, 50, 158-166. [CrossRef]

30. WoS. Web of Science. Journal Citation Reports. Available online: https://clarivate.com/webofsciencegroup/solutions/journalcitation-reports/ (accessed on 21 August 2020).

31. SRJ. Scimago Journal and Country Rank. Journal Rankings. Available online: https:/ /www.scimagojr.com/journalrank.php? area $=1100 \&$ country $=$ US (accessed on 21 May 2020).

32. Lusk, J.L.; Roosen, J.; Fox, J.A. Demand for Beef from Cattle Administered Growth Hormones or Fed Genetically Modified Corn: A Comparison of Consumers in France, Germany, the United Kingdom, and the United States. Am. J. Agric. Econ. 2003, 85, 16-29. [CrossRef]

33. Zwahlen, C.; Hilbeck, A.; Gugerli, P.; Nentwig, W. Degradation of the Cry1Ab protein within transgenic Bacillus thuringiensis corn tissue in the field. Mol. Ecol. 2003, 12, 765-775. [CrossRef] [PubMed]

34. Jarvis, D.I.; Hodgkin, T. Wild relatives and crop cultivars: Detecting natural introgression and farmer selection of new genetic combinations in agroecosystems. Mol. Ecol. 1999, 8, S159-S173. [CrossRef] [PubMed]

35. Zwahlen, C.; Hilbeck, A.; Howald, R.; Nentwig, W. Effects of transgenic Bt corn litter on the earthworm Lumbricus terrestris. Mol. Ecol. 2003, 12, 1077-1086. [CrossRef] [PubMed]

36. Gianessi, L.P. Economic and herbicide use impacts of glyphosate-resistant crops. Pest Manag. Sci. 2005, 61, 241-245. [CrossRef]

37. Ortiz-Garcia, S.; Ezcurra, E.; Schoel, B.; Acevedo, F.; Soberon, J.; Snow, A.A. Absence of detectable transgenes in local landraces of maize in Oaxaca, Mexico (2003-2004). Proc. Natl. Acad. Sci. USA 2005, 102, 12338-12343. [CrossRef] [PubMed]

38. Dively, G.P. Impact of Transgenic Vip3A $\times$ Cry1Ab Lepidopteran-resistant Field Corn on the Nontarget Arthropod Community. Environ. Ėntomol. 2005, 34, 1267-1291. [CrossRef]

39. Lundgren, J.G.; Wiedenmann, R.N. Coleopteran-specific Cry3Bb Toxin from Transgenic Corn Pollen Does Not Affect the Fitness of a Nontarget Species,Coleomegilla maculataDeGeer (Coleoptera: Coccinellidae). Environ. Èntomol. 2002, 31, 1213-1218. [CrossRef]

40. Faria, C.A.; Wäckers, F.L.; Pritchard, J.; Barrett, D.A.; Turlings, T.C. High Susceptibility of Bt Maize to Aphids Enhances the Performance of Parasitoids of Lepidopteran Pests. PLoS ONE 2007, 2, e600. [CrossRef]

41. Daly, T.; Buntin, G.D. Effect ofBacillus thuringiensisTransgenic Corn for Lepidopteran Control on Nontarget Arthropods. Environ. Èntomol. 2005, 34, 1292-1301. [CrossRef]

42. Davis, P.M.; Onstad, D.W. Seed mixtures as a resistance management strategy for European corn borers (Lepidoptera: Crambidae) infesting transgenic corn expressing Cry1Ab protein. J. Econ. Èntomol. 2000, 93, 937-948. [CrossRef] [PubMed]

43. Buntin, G.D.; Lee, R.D.; Wilson, D.M.; McPherson, R.M. Evaluation of Yieldgard Transgenic Resistance for Control of Fall Armyworm and Corn Earworm (Lepidoptera: Noctuidae) on Corn. Fla. Èntomol. 2001, 84, 37. [CrossRef]

44. Pilcher, C.D.; Rice, M.E.; Obrycki, J.J. Impact of TransgenicBacillus thuringiensisCorn and Crop Phenology on Five Nontarget Arthropods. Environ. Èntomol. 2005, 34, 1302-1316. [CrossRef]

45. Storer, N.P.; Van Duyn, J.W.; Kennedy, G.G. Life History Traits of Helicoverpa zea (Lepidoptera: Noctuidae) on Non-Bt and Bt Transgenic Corn Hybrids in Eastern North Carolina. J. Econ. Ėntomol. 2001, 94, 1268-1279. [CrossRef] [PubMed]

46. Onstad, D.W.; Guse, C.A.; Spencer, J.L.; Levine, E.; Gray, M.E. Modeling the dynamics of adaptation to transgenic corn by western corn rootworm (Coleoptera: Chrysomelidae). J. Econ. Ėntomol. 2001, 94, 529-540. [CrossRef] [PubMed]

47. Dyer, G.A.; Serratos-Hernández, J.A.; Perales, H.R.; Gepts, P.; Piñeyro-Nelson, A.; Chávez, A.; Salinas-Arreortua, N.; YúnezNaude, A.; Taylor, J.E.; Alvarez-Buylla, E.R. Dispersal of Transgenes through Maize Seed Systems in Mexico. PLoS ONE 2009, 4, e5734. [CrossRef] [PubMed]

48. He, K.; Wang, Z.; Zhou, D.; Wen, L.; Song, Y.; Yao, Z. Evaluation of Transgenic Bt Corn for Resistance to the Asian Corn Borer (Lepidoptera: Pyralidae). J. Econ. Èntomol. 2003, 96, 935-940. [CrossRef] [PubMed]

49. Pilcher, C.D.; Rice, M.E.; Higgins, R.A.; Steffey, K.L.; Hellmich, R.L.; Witkowski, J.; Calvin, D.; Ostlie, K.R.; Gray, M. Biotechnology and the European Corn Borer: Measuring Historical Farmer Perceptions and Adoption of Transgenic Bt Corn as a Pest Management Strategy. J. Econ. Ėntomol. 2002, 95, 878-892. [CrossRef] [PubMed]

50. Bitzer, R.J.; Rice, M.E.; Pilcher, C.D.; Pilcher, C.L.; Lam, W.-K.F. Biodiversity and Community Structure of Epedaphic and Euedaphic Springtails (Collembola) in Transgenic RootwormBtCorn. Environ. Ėntomol. 2005, 34, 1346-1376. [CrossRef]

51. Silva, T.H.P.; Moro, M.M.; Silva, A.P.C.; Meira, W.; Laender, A.H.F. Community-based endogamy as an influence indicator. In Proceedings of the IEEE/ACM Joint Conference on Digital Libraries, London, UK, 8-12 September 2014; pp. 67-76. [CrossRef]

52. Franco, R.; González, C.; Ramírez, J. Semilleros de Investigación vs. Comunidades Científicas ¿Moda ó Necesidad? Rev. Teckne 2016, 6, 35-37.

53. Vargas-Larreta, B.; Corral-Rivas, J.J.; Aguirre-Calderón, O.A.; López-Martínez, J.O.; Santos-Posadas, H.M.D.L.; Zamudio-Sánchez, F.J.; Treviño-Garza, E.J.; Martínez-Salvador, M.; Aguirre-Calderón, C.G. SiBiFor: Sistema Biome?trico Forestal para el manejo de los bosques de Me?xico. Rev. Chapingo Ser. Cienc. Ambient. 2017, 23, 437-455. [CrossRef]

54. Villegas, M.N.O.; Villarreal, L.Z.; Salvatierra, N.M.; Lara, O.G.H. Leyes de semillas y maíz transgénico. Análisis desde la co-producción entre ciencia y regímenes económico-políticos en México. Agric. Soc. Desarro. 2018, 15, 413-442. [CrossRef]

55. LDRS. Ley de Desarrollo Rural Sustentable. Diario Oficial de la Federación. Camara de Diputados del H. Congreso de la Unión. Ciudad de México. Available online: http:/ /www.diputados.gob.mx/LeyesBiblio/pdf/235_120419.pdf (accessed on 7 April 2020). 